\title{
PENAMAAN KULINER DALAM MASYARAKAT DAYAK MAANYAN
}

\author{
(Culinary Naming in Dayak Maanyan Community)
}

\author{
Dwiani Septiana \\ Balai Bahasa Kalimantan Tengah \\ Jalan Tingang Km 3,5, Palangka Raya, Kalimantan Tengah, Indonesia \\ Posel: dwianiseptiana22@gmail.com
}

\begin{abstract}
Abstrak: Penelitian ini bertujuan untuk mendeskripsikan penamaan kuliner dalam masyarakat Dayak Maanyan. Penelitian ini menggunakan teori onomastika sebagai bagian dari ilmu semantik yang mempelajari nama. Metode yang digunakan dalam penelitian adalah metode penelitian etnografi. Menurut Bramwell (2016) praktik penamaan yang digunakan dalam sebuah masyarakat dapat diteliti dengan penelitian etnografi. Pengumpulan data dilakukan dengan merekam dan mencatat semua leksikon yang berkaitan dengan nama-nama kuliner serta merekam dan mencatat pemahaman masyarakat Dayak Maanyan tentang kuliner dalam masyarakatnya. Analisis data dilakukan dengan mengklasifikasikan nama-nama kuliner berdasarkan jenis makanannya, mendeskripsikan strukturnya, menjelaskan maknanya, dan mendeskripsikan proses penamaannya. Berdasarkan hasil analisis data, dapat disimpulkan bahwa dari segi struktur kata, nama kuliner dalam bahasa Dayak Maanyan memiliki bentuk tunggal, bentuk turunan, dan bentuk majemuk. Dari segi proses penamaannya, nama kuliner dalam bahasa Dayak Maanyan dapat dikelompokkan menjadi tujuh jenis, yaitu penamaan berdasarkan keserupaan bentuk, rasa, cara pengolahan, tempat asal, peminjaman dari bahasa lain, bahan utama, dan manasuka penuturnya.
\end{abstract}

Kata Kunci: penamaan, kuliner, Dayak Maanyan, onomastika

Abstract: The purpose of this research is to describe culinary naming in Dayak Maanyan community. This research uses the theory of onomastics as part of semantics science that learn names. The method used in this research is ethnographic research methods. According to Bramwell (2016) naming used in a society can be investigated by ethnographic research. The data for this research are collected by recording all lexicons related to culinary names and recording the understanding of Dayak Maanyan community about culinary in their society. The results indicate that in terms of word structure, culinary names in the Dayak Maanyan language have single forms, derivative forms, and compound forms. In terms of naming process, the culinary names in the Dayak Maanyan language can be grouped into seven types: naming based on similarity in shape, taste, cooking process, place of origin, borrowing from other languages, main ingredient, and arbitrary by the speakers.

Keywords: naming, culinary, Dayak Maanyan, onomastics

\section{PENDAHULUAN}

Kuliner adalah segala sesuatu yang berhubungan dengan makanan dan masak-memasak. Istilah ini menjadi ramai dibicarakan di media televisi, media cetak, atau media sosial sejak sepuluh tahun terakhir. Selain memenuhi kebutuhan dasar manusia, yaitu makan dan makanan, kuliner juga mulai merambah ranah wisata. Istilah wisata kuliner menjadi tren, karena selain makan, orang-orang juga dapat berwisata dan dapat memenuhi hasrat aktualisasi 
diri di media sosial dengan mengunggah foto-foto wisata kuliner mereka pada media sosial pribadi. Dengan demikian, tidak dapat dimungkiri pada akhirnya kuliner menjadi salah satu andalan pariwisata daerah di Indonesia.

Salah satu daerah yang memiliki kekayaan kuliner dan kekayaan alam yang unik adalah Kalimantan. Penduduk asli pulau ini ialah masyarakat suku Dayak. Mereka memiliki beragam kuliner yang lezat dan sehat dengan cara pengolahan yang unik pula. Namun, kekayaan kuliner masyarakat Dayak kurang populer jika dibandingkan dengan kuliner masyarakat di daerah Sumatra Barat, misalnya, yang sangat terkenal dengan rendangnya yang mendunia. Oleh karena itu, peneliti tertarik untuk mengenalkan kuliner masyarakat Dayak, khususnya dalam penelitian ini, melalui nama-nama kuliner pada masyarakat Dayak Maanyan (selanjutnya akan disingkat dengan DM).

Masyarakat DM kebanyakan bermukim di sepanjang aliran anak Sungai Barito di daerah pegunungan di bagian selatan Provinsi Kalimantan Tengah. Lokasi ini membuat masyarakat DM kaya akan jenis-jenis kuliner yang berkaitan dengan ikan air tawar, binatang hasil berburu di hutan, serta sayur mayur yang disediakan alam. Selain lokasi permukiman, sistem religi masyarakat DM zaman dahulu juga banyak menyumbangkan kekayaan kuliner masyarakat ini.

Keunikan kuliner masyarakat DM juga disertai dengan keunikan penamaannya. Pemberian nama pada makhluk hidup, benda, aktivitas, dan peristiwa dapat berdasarkan pada bunyi benda atau suara yang ditimbulkan oleh benda tersebut, keserupaannya dengan benda lain, atau tempat asal ditemukannya benda tersebut (Chaer dalam Kusumaningtyas, Wibisono, dan Kusnadi, 2013, hlm. 2). Dalam masyarakat DM terdapat makanan yang disebut dengan edeh punei 'kotoran burung Punai', dari namanya terkesan jorok, tetapi penamaan makanan tersebut sebenarnya berdasarkan pada bentuknya yang mirip dengan kotoran burung tersebut.

Hagström (2012, hlm. 83) mengatakan bahwa nama dapat membantu manusia dalam menciptakan keteraturan dan menyusun pemahaman tentang dunia. Menurutnya melalui penamaan, dunia menjadi dapat dimengerti, manusia dapat mengklasifikasikan dan mengatur lingkungan hudupnya. Begitu pula dalam masyarakat DM. Mereka menamai tiap jenis kulinernya agar tercipta keteraturan dan memudahkan mereka untuk menurunkan kekayaaan kuliner tersebut dari generasi ke generasi. Meskipun begitu, seiring perkembangan zaman dan masuknya sistem religi baru ke dalam masyarakat ini, banyak dari kekayaan kuliner tadi yang sudah jarang ditemui. Bahkan, kuliner yang berkaitan dengan upacara keagamaan zaman dahulu sebagian hanya tinggal nama.

Melihat fonomena tersebut, peneliti tertarik untuk meneliti tentang penamaan, bentuk, dan makna nama kuliner dalam masyarakat DM. Agar penelitian ini terarah, permasalahan yang akan dibahas dalam penelitian ini adalah bagaimana penamaan kuliner dalam masyarakat DM. Tujuan yang hendak dicapai penelitian ini adalah mendeskripsikan penamaan kuliner dalam masyarakat DM.

Penelitian ini diharapkan dapat memberikan manfaat bagi masyarakat di luar DM berupa pemahaman dan pengetahuan tentang kuliner dan budaya masyarakat DM. Di samping itu, penelitian ini diharapkan bermanfaat sebagai salah satu upaya dokumentasi terhadap leksikon yang berkaitan dengan kuliner sehingga dapat dijadikan acuan dalam pembuatan kamus bahasa DM. 
Penelitian terdahulu yang berhubungan dengan penelitian ini, antara lain, penelitian tentang leksikon makanan tradisional Sunda di Kabupaten Kuningan (Hadiyaniyah, 2016). Penelitian tersebut mendeskripsikan bentuk lingual, penamaan, makna leksikon, dan bahan dasar makanan tradisional Sunda di Kabupaten Kuningan secara deskriptif. Berdasarkan hasil penelitiannya, Hadiyaniyah menemukan bahwa dalam makanan tradisional Sunda terdapat 73 nama makanan yang diklasifikasikan berdasarkan bentuknya, yaitu kata dasar, kata imbuhan, kata ulang, kata majemuk, dan kata singkatan. Penamaan makanan tradisional Sunda didasarkan pada bahan, tempat asalnya, sifat khasnya, anggapan masyarakat, dan manasuka. Berdasarkan penelitian tersebut dapat disimpulkan bahwa penelitian ini memiliki persamaan dan perbedaan. Persamaannya terletak pada objek penelitian yang sama, yaitu nama-nama makanan dalam sebuah masyarakat. Perbedaan penelitian ini dengan penelitian sebelumnya terletak pada permasalahan yang akan dikaji dan metode yang digunakan dalam penelitian. Selain itu, menurut pengamatan peneliti belum ada penelitian sebelumnya yang membahas tentang leksikon kuliner pada masyarakat Maanyan dalam disiplin ilmu linguistik.

Penelitian ini menggunakan teori onomastika sebagai bagian dari ilmu semantik. Teori onomastika dalam semantik digunakan untuk menganalisis makna nama dan melihat pola penamaan kuliner dalam masyarakat DM.

Semantik adalah ilmu yang mempelajari tentang makna bahasa (Murphy, 2010, hlm. 3). Menurut Chaer (2007, hlm. 289) makna dalam sebuah bahasa dapat bermacam-macam karena bahasa digunakan untuk berbagai kegiatan dan keperluan dalam kehidupan bermasyara-kat. Salah satu makna yang dimaksud adalah makna leksikal. Makna leksikal sendiri dapat berarti makna kata ketika kata itu berdiri sendiri, dalam bentuk leksem atau berimbuhan yang maknanya kurang lebih tetap (Pateda, 2001, hlm. 119). Pendapat yang sama juga diungkapkan oleh Chaer (2007, hlm. 289) yang mengatakan bahwa makna leksikal adalah makna yang dimiliki atau ada pada sebuah kata meski tanpa konteks apa pun. Bila Chaer dan Pateda menggunakan istilah kata untuk mengacu pada makna leksikal, Murphy (2010, hlm. 3) menggunakan istilah leksikon. Menurutnya makna leksikal dalam semantik mengacu pada leksikon. Leksikon merupakan kumpulan informasi tentang kata dalam sebuah bahasa. Leksikon juga dapat mengacu pada kosakata dalam sebuah bahasa atau pengetahuan tertentu dari pengguna bahasa tentang kosakata dalam bahasa mereka (Murphy, 2010, hlm. 3-4). Dalam penelitian ini yang dimaksud dengan leksikon atau kata yang akan diungkap makna leksikalnya adalah nama-nama kuliner dalam masyarakat DM.

Onomastika merupakan cabang dari ilmu semantik yang mempelajari etimologi nama (Crystal, 2008, hlm. 339). KBBI (2016) mendefinisikan onomastika sebagai penyelidikan tentang asal-usul, bentuk, dan makna nama diri. Onomastika dikenal sebagai ilmu yang mempelajari nama. Sejak zaman Yunani kuno, nama memang telah dianggap sebagai pusat kajian tentang bahasa yang menyoroti bagaimana manusia saling berkomuni-kasi (Hough, 2016, hlm. 1). Jadi, dapat disimpulkan bahwa onomastika merupakan cabang ilmu semantik yang mempelajari bentuk, makna, dan asal-usul nama.

Kata nama sering digunakan untuk istilah yang dapat mengacu pada apa pun (Bright, 2003, hlm. 670). Penamaan tidak hanya terbatas pada 
nama orang atau tempat, tetapi dapat mencakupi makhluk hidup lainnya, benda-benda buatan manusia, bendabenda langit, dan segala sesuatu yang mencerminkan berbagai aspek interaksi antara manusia dan lingkungannya (Hough, 2016, hlm. 1). Menurut Chaer dalam Kusumaningtyas dkk. (2013, hlm. 1) pemberian nama pada makhluk hidup, benda, aktivitas, dan peristiwa dapat dilakukan berdasarkan pada bunyi dari benda atau suara yang ditimbulkan oleh benda tersebut, keserupaannya dengan benda lain, atau tempat asal ditemukannya benda tersebut. Pemberian nama juga dapat meminjam atau mengambil nama dari bahasa lain. Sandnes (2016, hlm. 553) mengatakan bahwa nama dapat dipinjam dari bahasa lain. Untuk memudahkan beradaptasi dengan sistem bahasa yang baru, nama yang dipinjam dapat disesuaikan dengan sistem bunyi atau suara bahasa penerimanya. Jadi, proses penamaan dalam sebuah bahasa dapat berdasarkan bunyi, keserupaan, tempat asal, dan peminjaman dari bahasa lain. Dalam penelitian ini nama yang dimaksud berkaitan dengan kuliner dalam masyarakat DM.

\section{METODE PENELITIAN}

Penelitian ini menggunakan metode penelitian etnografi. Bramwell (2016, hlm. 269) mengatakan bahwa praktik penamaan yang digunakan dalam sebuah masyarakat dapat diteliti dengan penelitian etnografi. Menurutnya dalam penelitian etnografi peneliti berbaur dalam sebuah masyarakat selama periode waktu tertentu, merekam semua temuan dengan menulis catatan lapangan dengan tujuan akhirnya adalah untuk mendapatkan pemahaman dari perspektif penduduk lokal tentang apa yang terjadi, bagaimana, dan mengapa sesuatu hal dapat terjadi. Dalam penelitian tentang penamaan kuliner ini peneliti terlibat dalam masyarakat DM, merekam, dan mencatat semua leksikon yang berkaitan dengan nama-nama kuliner serta mencatat pemahaman masyarakat DM tentang kuliner dalam masyarakatnya.

Analisis data dilakukan dengan mengklasifikasi nama-nama kuliner berdasarkan jenis makanannya, mendeskripsikan strukturnya, menjelaskan maknanya, mendeskripsikan proses penamaannya, dan membuat simpulan sehingga akan menghasilkan deskripsi yang lengkap tentang nama-nama kuliner dalam masyarakat DM.

\section{PEMBAHASAN}

Deskripsi tentang nama-nama kuliner dalam masyarakat DM akan dibagi menjadi dua, yaitu deskripsi terhadap struktur nama dan deskripsi terhadap makna dan proses penamaan kuliner dalam masyarakat DM.

\section{Struktur Nama Kuliner dalam Masyarakat DM}

Berdasarkan struktur katanya namanama kuliner dalam bahasa DM terdiri atas bentuk tunggal, bentuk turunan, dan bentuk majemuk. Berikut merupakan deskripsi nama-nama kuliner dalam masyarakat DM dilihat dari struktur katanya.

\section{a. Bentuk Tunggal}

Bentuk tunggal dalam deskripsi ini mengacu pada nama-nama kuliner yang hanya terdiri atas satu kata tunggal, tanpa proses afiksasi atau reduplikasi. Dilihat dari jumlah suku katanya, namanama tersebut dapat dibedakan sebagai berikut.

1. Nama dengan dua suku kata, seperti wadi, puka, pike, paku, pais, salai, kulat, kiping, tumpi, papai, upi, uwut, dan tungkul. Berdasarkan pola suku katanya, nama-nama tersebut dapat dideskripsikan ke dalam sembilan pola suku kata, yaitu sebagai berikut. 
1) $\mathrm{KV}-\mathrm{KV}$, seperti pada $w a-d i, p u-k a$, pi-ke, pa-ku;

2) KV-VK, seperti pada $p a-i s$;

3) KV-VK, seperti pada pa-ing, teung;

4) KV-KV seperti pada sa-lai, pa-pai, wa-wui;

5) KV-KVK, seperti pada ku-lat, siwak, ki-ping, la-mang

6) KVK-KV, seperti pada tum-pi,

7) KVK-KVK, seperti pada tung-kul;

8) V-KV, seperti pada $u$-pi; dan

9) V-KVK, seperti pada $u$-wut

2. Nama dengan tiga suku kata, seperti kalumpe, lammayung, gagatas, gaguduh, awatei, kadiki. Berdasarkan pola suku katanya nama-nama tersebut dapat dideskripsikan ke dalam lima pola suku kata.

1) $\mathrm{KV}-\mathrm{KVK}-\mathrm{KV}$, seperti pada $k a$ lum-pe;

2) KVK-KV-KVK, seperti pada lamma-yung;

3) KV-KV-KVK, seperti pada ga-gatas, ga-gu-duh;

4) KV-KV-KV, seperti pada $k a-d i-k i$; dan

5) V-KV-KVK, seperti pada $a$-wa-tei

3. Nama dengan empat suku kata, seperti pakingkin, kuruwila, pulumpunti. Berdasarkan pola suku katanya namanama tersebut dapat dideskripsikan ke dalam dua pola suku kata, yaitu,

1) KV-KVK-KVK, seperti pada $p a-$ king-kin; dan

2) $\mathrm{KV}-\mathrm{KV}-\mathrm{KV}-\mathrm{KV}$, seperti pada $k u$ ru-wi-la;

Berdasarkan deskripsi di atas, terlihat bahwa dari struktur suku katanya nama kuliner dalam DM bentuk tunggal ada tiga jenis, yaitu nama kuliner dengan dua suku kata dapat dikelompokkan ke dalam sembilan pola suku kata, nama kuliner dengan tiga suku kata dikelompokkan ke dalam lima pola, dan nama kuliner dengan empat suku kata dikelompokkan ke dalam dua pola b. Bentuk Turunan
Bentuk turunan dalam deskripsi ini mengacu kepada nama-nama kuliner yang mengalami proses afiksasi, reduplikasi, dan abreviasi. Afiksasi merupakan proses morfologis yang mengubah leksem menjadi kata; reduplikasi merupakan proses morfologis yang mengubah sebuah leksem menjadi kata setelah mengalami proses pengulangan baik pengulangan suku awal, penuh, penuh yang berubah bunyi, maupun suku akhir; dan abreviasi merupakan proses yang mengubah leksem atau gabungan leksem menjadi kependekan (Arifin dan Junaiyah, 2009, hlm. 9). Struktur nama kuliner dalam masyarakat DM ada yang dibentuk melalui ketiga proses tersebut.

1. Afiksasi

Nama kuliner termasuk dalam kelas kata nomina. Salah satu afiks pembentuk nomina dalam bahasa DM adalah sufiks -an. Dalam membentuk nomina, sufiks -an dapat bergabung dengan verba atau adjektiva.

1) verba + -an

papahak 'merebus'+ -an $\rightarrow$ papahakan 'rebusan'

upuh 'membakar' + -an $\rightarrow$ upuhan 'bakaran'

tanak 'menanak'+ -an $\rightarrow$ tanakan 'tanakan'

dadah 'memanggang' + -an $\rightarrow$ dadahan 'panggangan'

2) adjektiva $+-a n$

wayuwu 'hambar' +-an $\rightarrow$ wayuwuan 'nama jenis masakan'

Selain termasuk dalam kelas kata nomina ada pula nama kuliner yang masuk dalam kelas kata verba, yaitu dengan menambahkan prefiks ta-. Penambahan prefiks $t a$ - pada kelas kata selain verba akan mengubah kelas katanya menjadi verba.

3) $t a-+$ adjektiva ta- + luya 'lembek' $\rightarrow$ tanuya 'membuat sesuatu menjadi lembek' 


\section{Reduplikasi}

Bentuk reduplikasi dalam bahasa DM kebanyakan merupakan bentuk reduplikasi sebagian. Bentuk reduplikasi pada nama kuliner babutup dibentuk dengan mengulang suku kata awal dengan perubahan fonem vokal pada suku kata pertama menjadi fonem /a/ (Septiana, 2015, hlm. 348). Nama tersebut berasal dari bentuknya yang butup-butup 'berbongkal-bongkal'

butup 'bongkal' $\rightarrow$ bu-butup $\rightarrow$ babutup 'berbongkal-bongkal'.

Bentuk reduplikasi dengan pengulangan seluruh kata jarang digunakan dalam bahasa DM.

\section{Abreviasi}

Pembentukan nama kuliner melalui proses abreviasi dilakukan dengan menyingkat gabungan kata menjadi kata baru. Nama kaluit [kaluwit] berasal dari kata kaluar [kalu $\left.{ }^{\mathrm{w}} \mathrm{ar}\right]$ 'keluar' dan kata utit [utit] 'sedikit', disingkat menjadi kalu-it yang berarti 'keluar sedikit'.

Dari penjelasan di atas terlihat bahwa dalam nama kuliner bahasa DM terdapat bentuk turunan, yaitu namanama kuliner yang dibentuk melalui afiksasi, reduplikasi, dan abreviasi. Melalui afiksasi, nama kuliner dapat dibentuk dengan menambahkan sufiks an pada kelas kata verba dan adjektiva serta penambahan prefiks $t a$ - pada kelas kata adjektiva. Melalui reduplikasi, nama kuliner dalam bahasa DM dapat dibentuk dengan mengulang suku kata awal yang mengalami perubahan fonem awalnya menjadi fonem /a/. Melalui abreviasi nama kuliner dalam bahasa DM dibentuk dengan menyingkat dua suku kata pertama dan satu suku kata terakhir dari gabungan dua kata.

c. Bentuk Majemuk

Bentuk majemuk dalam deskripsi ini mengacu pada nama-nama kuliner yang terdiri atas gabungan dua kata atau lebih. Terdapat empat pola penggabungan kata dalam nama-nama kuliner.

1) Nomina + Nomina

Nama kuliner dalam masyarakat DM dapat dibentuk dengan menggabungkan kelas kata nomina dan nomina, seperti

Edeh 'tahi' + punei 'burung Punai' $\rightarrow$ edeh punei 'nama kue yang terbuat dari tepung beras dan ketan'

Diki 'biji' + manau 'buah Manau $\rightarrow$ diki manau "nama kue yang terbuat dari tepung beras dan ketan'

Pusuk 'pucuk'+ suku 'singkong' $\rightarrow$ pusuk suku 'sayur dari daun muda pohon ketela'

Pusuk 'pucuk' + katila 'pepaya' $\rightarrow$ pusuk katila 'sayur dari daun muda pohon pepaya'

2) Nomina + Adjektiva

Nama kuliner dalam masyarakat DM dapat dibentuk dengan menggabungkan kelas kata nomina dan adjektiva, seperti

Kenah 'ikan'+ karing 'kering' $\rightarrow$ kenah karing 'ikan yang diasinkan dan dijemur sampai kering'

Teung 'terung' + asem 'masam' $\rightarrow$ teung asem 'terung yang rasanya asam, bentuknya bulat, dan berwana kuning'

3) Verba + Nomina

Nama kuliner dalam masyarakat DM dapat dibentuk dengan menggabungkan kelas kata verba dan nomina, seperti

Pais 'membuat pepes'+ kenah 'ikan' $\rightarrow$ pais kenah 'pepes ikan'

4) Nomina + Numeralia

Nama kuliner dalam masyarakat DM ada dibentuk dengan menggabungkan kelas kata nomina dan numeralia, seperti

Wadai 'kue'+ satu 'angka satu' $\rightarrow$ wadai satu 'kue kering yang terbuat dari ketan'.

Berdasarkan deskripsi di atas terlihat bahwa dalam bahasa DM terdapat bentuk pemajemukan atau penggabungan kata yang dibentuk 
dengan empat pola, yaitu menggabungkan kelas kata nomina dan nomina, nomina dan adjektiva, nomina dan verba, serta nomina dan numeralia.

\section{Makna dan Proses Penamaan Kuliner dalam Masyarakat DM}

Selain dideskripsikan berdasarkan struktur katanya, penamaan kuliner dalam masyarakat DM juga dideskripsikan berdasarkan makna dan proses penamaannya.

1. Makna Nama-Nama Kuliner dalam Masyarakat DM

Deskripsi makna nama-nama kuliner dalam bahasa DM akan diklasifikasi berdasarkan jenis makanannya, yaitu makanan utama dan makanan kecil. Makanan utama adalah jenis makanan yang biasa dimakan tiga kali sehari, saat sarapan atau makan pagi, makan siang, dan malam. Makanan kecil adalah kue-kue khas dalam masyarakat DM.

a. Nama Makanan Utama dalam Kuliner Masyarakat DM

Berikut merupakan deskripsi makna nama makanan dalam kuliner masyarakat DM yang biasanya dimakan sebagai makanan utama.

Nahi [nahiq] adalah makanan pokok masyarakat DM yang terbuat dari beras yang telah dimasak. Nahi berasal dari bahasa Indonesia nasi. Nama tersebut dipakai dengan mengadaptasinya ke sistem bunyi atau suara bahasa DM.

Tanuya [tanuyaq] ialah makanan yang terbuat dari beras yang direbus dengan menggunakan air yang lebih banyak sehingga membuatnya menjadi lembek dan berair, dalam bahasa Indonesia disebut dengan bubur. Makanan ini biasanya diberikan kepada orang sakit atau orang yang sudah tua. Nama tanuya berasal dari kata luya [luyaq] yang berarti lembek atau berair sehingga tanuya berarti membuat sesuatu menjadi seperti luya.
Dite [diteq] adalah makanan yang terbuat dari beras ketan. Nama dite juga berarti getah. Karena bentuk dite yang lengket seperti getah, nama tersebut juga dipakai sebagai nama makanan yang terbuat dari beras ketan tersebut. Dite biasanya diolah menjadi makanan sampingan seperti lamang [lamay] yang dimasak dengan menggunakan santan dan bumbu serta dipanggang dalam bambu sehingga menghasilkan rasa gurih. Olahan wajik [wajik] juga dapat dibuat dari campuran dite dengan gula merah sehingga menghasilkan rasa yang manis. Lamang dan wajik bukan kue khas masyarakat DM, melainkan dikenal juga di berbagai daerah di Indonesia.

Papahakan [papahakan] merupakan rebusan ikan atau daging dengan bumbu. Ikan atau daging direbus dengan bumbu sampai air atau kuahnya sedikit dan mengental. Nama papahakan berasal dari kata kerja papahak yang berarti merebus.

Babutup [babutup] ialah makanan yang terbuat dari ikan yang sudah hampir busuk. Ikan ditanak dengan bumbu kunyit dan serai sampai agak kering. Daging ikan yang lepas dari tulangnya menghasilkan gumpalangumpalan daging. Itulah alasan mengapa makanan ini diberi nama babutup karena bentuknya yang menggumpal-gumpal yang dalam bahasa DM disebut dengan butup-butup.

Tanakan [tanakan] adalah nama makanan dengan bahan utamanya ikan yang diberi bumbu kuning dan direbus sampai airnya kering. Nama tanakan diambil dari proses mengolahnya, yaitu tanak atau nanak yang berarti memasak sesuatu sampai airnya mengering.

Wadi [wadiq] adalah makanan khas masyarakat DM yang terbuat dari ikan atau daging yang diawetkan dengan garam dan samu [samuq] atau tumbukan beras ketan yang disangrai. Setelah mengalami proses pengawetan selama beberapa hari atau bahkan bulan di 
dalam setoples kaca atau guci, makanan ini akan terasa sangat asin dan asam. Wadi biasa dimakan dengan rebusan sayuran yang biasanya ditanam di ladang, seperti lammayung [lammayun] 'kacang panjang', pusuk suku [pusuk suku:] 'pucuk daun singkong, pusuk katila [pusuk katilaq] 'pucuk daun pepaya', dan teung [te'uy] 'terong'. Wadi yang terbuat dari daging (biasanya wawui [wawuy] 'babi hutan') dimasak dengan ditanak sampai dagingnya lembut dengan sedikit kuah sehingga makanan ini disebut dengan tanakan wadi.

Pakasem [pakasem] ialah makanan yang terbuat dari ikan atau daging yang diawetkan dengan menggunakan nasi dan garam. Setelah mengalami proses pengawetan, makanan ini akan terasa asam dan asin. Oleh karena itu, makanan ini dinamai pakasem berasal dari kata asem yang dalam bahasa DM berarti asam. Pakasem memiliki rasa yang hampir sama dengan wadi hanya bahan untuk pengawetannya yang sedikit berbeda.

Upuhan [upuhan] berarti bakaran atau panggangan. Nama upuhan berasal dari kata kerja ngupuh [yupuh] 'membakar'. Dalam kuliner masyarakat DM beberapa jenis ikan dan sayuran dapat diolah menjadi upuhan. Berbagai jenis ikan yang bersisik dapat dibakar dengan sisiknya dan disebut dengan upuhan kenah [upuhan kenah] 'ikan bakar'. Selain ikan segar ikan yang sudah dikeringkan, kenah karing [kenah karin] 'ikan asin' pun dapat diolah menjadi upuhan. Selain ikan, sayuran pun dapat diolah menjadi upuhan, yaitu upuhan teung [upuhan te $\mathrm{e}^{\mathrm{y}} \mathrm{u}$ ] 'terong bakar' dan upuhan rereh [upuhan rerch] 'buah cempedak muda yang dibakar' biasanya dimakan dengan mencocolnya pada sambal atau wadi.

Pais $\left[\mathrm{pa}^{\mathrm{y}}\right.$ is] dalam kuliner DM ada dua jenis, ada yang terbuat dari ikan yang diberi bumbu dengan kunyit dan dibungkus daun pisang, digunakan sebagai lauk teman makan nasi, ada pula pais yang terbuat dari adonan tepung beras yang dicampur dengan buah pisang atau waluh.

Awatei [awatey] ialah nama ulat kumbang pada tebangan batang pohon rumbia yang sudah membusuk. Awatei dapat dimakan langsung, dapat pula dimasak dengan cara menggorengnya, atau dimasak dengan bamenu [bamenuq] yaitu sejenis daun yang rasanya asam.

Paing [pa ${ }^{\mathrm{y}} \mathrm{in]}$ ialah nama sejenis kelelawar pemakan buah-buahan. Orang DM biasanya membersihkan paing dengan menggantungnya terbalik dan membuang beberapa bagian tubuhnya, seperti telinga, kaki dan kuku, serta bulu pada bagian leher. Daging dan beberapa bagian sayap dan kulit bulunya direbus dengan air dan diberi garam sampai daging lembut dan biasanya disebut dengan luen paing 'masakan paing'. Luen paing sering kali diberi siwak [siwak], batang pohon pisang yang diambil bagian tengahnya, atau lantar upi [lantar upiq] 'sulur keladi'. Daging paing dapat pula diolah menjadi wadi.

Wayuwuan [wayuwu'wan] ialah nama rebusan sayuran dengan kuah bening. Dalam kuliner DM kebanyakan sayur dimasak dengan ikan atau daging yang disebut dengan luen [lu $\left.\mathrm{u}^{\mathrm{w} e n}\right]$ atau lauk makanan pendamping nasi. Nama wayuwuan berasal dari kata kerja wayuwu yang berarti memasak sayur tanpa ikan atau daging.

Kalumpe [kalumpeq] adalah nama makanan yang terbuat dari pucuk daun singkong yang ditumbuk halus dengan bumbu dan dimasak dengan santan, sering kali ditambahkan dengan teung tangurit 'terung pipit'. Di beberapa daerah, masyarakat DM juga menamai makanan ini karuang [karuqay].

Puka [pukaq] ialah nama batang bambu yang masih muda atau rebung. Puka diolah dengan diiris tipis-tipis dan 
diberi bumbu, disebut luen rakanan puka 'masakan rebusan rebung'.

Pike [pikeq] adalah nama sejenis tanaman pakis atau paku yang diambil daun dan batang mudanya yang berwarna hijau. Pike dapat direbus dengan baluh 'waluh', kuruwila 'gambas', atau sayuran lainnya dengan ditambah ikan yang sudah dipanggang. Makanan ini biasanya disebut luen pike 'masakan pike'. Tanaman sejenis pike yang dapat diolah menjadi makanan adalah paku [paku:] atau pakis.

Papai [papay] ialah nama makanan yang terbuat dari kulit buah cempedak. Orang DM biasanya menyimpan dan mengawetkan papai di dalam toples kaca atau guci sebagai persediaan makanan pendamping nasi. Papai yang sudah diawetkan akan terasa asam dan asin.

Uwut [uwut] ialah umbut rotan atau kelapa. Umbut rotan dinamai $u w u t$ nange [uwut nayE] dan umbut kelapa uwut niui [uwut ni ${ }^{\mathrm{y}} \mathrm{uy}$ ]. Uwut biasanya dimasak dengan ayam, daging, atau ikan. Makanan ini disebut luen uwut.

Dadahan [dadahan] ialah nama makanan yang dibuat dengan memanggang. Dadah dalam bahasa DM berarti memanggang. Salah satu jenis sambal ada yang bernama dadahan asan 'panggang terasi', yaitu terasi, irisan serai, lombok dan garam yang diulek pada cobek dan dipanggang dalam posisi terbalik menghadap bara.

b. Nama Makanan Kecil dalam Kuliner Masyarakat DM

Berikut merupakan deskripsi makna nama makanan kecil atau kue-kue khas dalam kuliner masyarakat DM.

Kiping [kipin] ialah nama kue khas masyarakat DM. Adonan kue ini dibuat dari campuran tepung beras dan tepung ketan yang dibentuk bulat-bulat gepeng, seperti kepingan uang logam. Adonan direbus dengan santan dan gula merah sampai mengental dan menjadi seperti bubur. Nama kiping berasal dari bentuk adonan yang menyerupai kepingan uang logam.

Diki manau [diki: manaw] adalah nama kue khas masyarakat DM artinya biji manau. Kue ini hampir sama dengan kiping, hanya bentuk adonannya yang berbeda. Adonan diki manau dibentuk bulat-bulat kecil seukuran dengan biji buah manau.

Edeh punei [ $\varepsilon \mathrm{d} d \mathrm{ch}$ puney] secara harfiah nama kue ini berarti kotoran (tahi) burung punai. Edeh punei memiliki rasa yang hampir sama dengan kiping dan diki manau, hanya bentuk adonannya yang berbeda. Kue ini lebih kental dibanding dengan kiping dan diki manau dengan adonan yang menyerupai bentuk kotoran burung punai. Oleh karena itulah kue ini dinamai edeh punei.

Tumpi [tumpiq] ialah nama kue yang terbuat dari tepung ketan, dibentuk persegi empat dan digoreng. Nama kue ini cukup terkenal di kalangan masyarakat DM karena dipakai sebagai lirik dalam lagu tradisional "Tumpi Wayu".

Gagatas [gagatas] adalah nama kue yang terbuat dari tepung ketan, dibentuk persegi atau jajaran genjang, digoreng, dan dilumuri gula. Nama gagatas diambil dari bentuknya yang jajaran genjang yang dalam bahasa DM disebut gagatas.

Kaluit [kaluwit] ialah nama kue yang dibuat dari adonan tepung ketan, dibentuk segi tiga, di dalamnya diisi dengan inti 'parutan kelapa muda yang dicampur gula merah', dan dibungkus dengan daun pisang.

Pakingkin [pakinkin] adalah nama sejenis kue yang terbuat dari beras ketan yang dimasak di dalam bambu kecil. Kue ini tidak memiliki rasa, biasanya dipakai sebagai kue-kue yang dipersembahkan kepada roh nenek moyang.

Gaguduh [gaguduh] merupakan nama kue yang terbuat dari adonan tepung terigu bersama buah-buahan dan 
digoreng. Buah yang bisa dijadikan gaguduh contohnya nanakan 'cempedak', punsi 'pisang', dan papuan 'buah papuan'.

2. Proses Penamaan Kuliner dalam Masyarakat DM

Proses penamaan dalam sebuah bahasa dapat berdasarkan bunyi, keserupaan bentuknya, rasa, cara pengolahan, tempat asal, peminjaman dari bahasa lain, atau manasuka penuturnya. Penamaan kuliner dalam bahasa DM dapat dikelompokkan menjadi tujuh jenis berikut.

a. Penamaan Berdasarkan Keserupaan Bentuk

Nama kuliner dalam masyarakat DM ada yang dibuat berdasarkan kesamaan makanan tersebut dengan bentuknya. Penamaan menurut cara ini terdapat sebelas jenis makanan, yaitu dite, wajik, tanuya, babutup, kiping, diki manau, edeh punei, gagatas, pakingkin, kenah karing, dan kaluit

b. Penamaan Berdasarkan Proses Pengolahan

Nama kuliner dalam massyarakat DM ada yang dibuat berdasarkan proses pengolahannya. Penamaan menurut cara ini terdapat lima jenis makanan, yaitu papahakan, upuhan, tanakan, wayuwuan, dan dadahan.

c. Penamaan Berdasarkan Rasa Makanan

Nama kuliner dalam masyarakat DM ada yang dibuat berdasarkan rasa makanan tersebut. Terdapat dua jenis nama makanan menurut cara ini, yaitu: pakasem dan teung asem.

d. Penamaan Berdasarkan Tempat

Nama kuliner dalam masyarakat DM ada yang dibuat berdasarkan tempatnya. Terdapat jenis bumbu masakan yang dinamai bawang ume, yaitu jenis bawang yang ditanam di ladang atau dalam bahasa DM disebut ume [ume] e. Penamaan Berdasarkan Pinjaman dari Bahasa Lain

Nama kuliner dalam masyarakat DM ada yang dipinjam dari bahasa lain dan disesuaikan dengan sistem bunyi atau kaidah fonologis bahasa DM. Terdapat enam jenis makanan menurut cara ini, yaitu nahi, pais, salai, tampuyak, lamang, dan tungkul.

f. Penamaan Berdasarkan Bahan Utama Masakan

Nama kuliner dalam masyarakat DM ada yang disebut berdasarkan bahan utama masakah tersebut, yaitu luen paing, luen puka, luen pike, dan luen uwut.

g. Penamaan berdasarkan manasuka

Manasuka berarti sesuka hati. Nama kuliner dalam masyarakat DM ada yang dibuat berdasarkan manasuka, seperti wadi, kalumpe, tumpi, dan papai.

\section{PENUTUP}

Berdasarkan deskripsi tentang penamaan kuliner dalam masyarakat DM dapat disimpulkan beberapa hal berikut.

1. Dari struktur suku katanya namanama kuliner dalam bahasa DM terdiri atas bentuk tunggal, bentuk turunan, dan bentuk majemuk. Dalam bentuk tunggal terdapat nama kuliner dengan dua suku kata, tiga suku kata, dan empat suku kata yang memiliki pola masing-masing. Dalam bentuk turunan terdapat namanama kuliner yang dibentuk melalui afiksasi, reduplikasi, dan abreviasi. Dalam bentuk majemuk nama kuliner dalam bahasa DM dibentuk dengan menggabungkan kelas kata nomina dan nomina, nomina dan adjektiva, nomina dan verba, serta nomina dan numeralia.

2. Berdasarkan proses penamaannya nama kuliner dalam bahasa DM dikelompokan menjadi tujuh jenis, yaitu berdasarkan keserupaan bentuknya, rasa, cara pengolahan, tempat asal, 
peminjaman dari bahasa lain, bahan utama, dan manasuka penuturnya.

\section{DAFTAR PUSTAKA}

Arifin, Z., \& Junaiyah. (2009). Morfologi Bentuk, Makna, dan Fungsi. Jakarta: Grasindo.

Bramwell, E. S. (2016). Personal Names and Anthropology. In C. Hough (Ed.), The Oxford Handbook of Names and Naming (pp. 264-278). Oxford University Press. http://doi.org/10.1093/oxfordhb/978 0199656431.013 .29

Bright, W. (2003). What IS a Name? Reflections on Onomastics. Language and Linguistics, 4(February), 669-681.

Chaer, A. (2007). Linguistik Umum. Jakarta: Rineka Cipta.

Crystal, D. (2008). A Dictionary of Linguistics and Phonetics (6th ed.). Oxford: Blackwell Publishing.

Hadiyaniyah, Y. N. (2016). Leksikon Makanan Tradisional Sunda di Kabupaten Kuningan (Kajian Etnolinguistik). Lokabasa, 7(1), 94-102.

Hagström, C. (2012). Naming Me, Naming You. Personal Names, Online Signatures and Cultural Meaning. Names and Identitiy, 4(2), 82-93.

Hough, C. (2016). Introduction. In C. Hough (Ed.), The Oxford Handbook of Names and Naming (pp. 1-14). Oxford University Press. http://doi.org/10.1093/oxfordhb/978 0199656431.013.47

KBBI Daring. (2016). Retrieved from https://kbbi.kemdikbud.go.id/entri/o nomastika
Kusumaningtyas, A., Wibisono, B., \& Kusnadi. (2013). Penggunaan Istilah Makanan dan Jajanan Tradisional Pada Masyarakat di Kabupaten Banyuwangi Sebuah Kajian Etnolinguistik. Publika Budaya, 1(1), 1-9.

Murphy, M. L. (2010). Lexical Meaning. Cambridge: Cambridge University Press.

Pateda, M. (2001). Semantik Leksikal. Jakarta: Rineka Cipta.

Sandnes, B. (2016). Names and Language Contact. In C. Hough (Ed.), The Oxford Handbook of Names and Naming (pp. 541-553). Oxford University Press. http://doi.org/10.1093/oxfordhb/978 0199656431.013 .33

Septiana, D. (2015). Reduplikasi dalam Bahasa Dayak Maanyan. Sawerigading, 21(2), 343-354. 